\title{
The Chinese foreign direct investment to Sub-Sahara Africa
}

\author{
M. Michael ${ }^{1,2 \otimes}$, E.O. Glory ${ }^{2}$, O. Sylvester ${ }^{1}$, O.T. Daniel ${ }^{3}$ \\ ${ }^{1}$ Peoples' Friendship University of Russia (RUDN University), \\ 6 Miklukho-Maklaya St, Moscow, 117198, Russian Federation \\ ${ }^{2}$ Ambrose Alli University,
}

KM 70 Benin Auchi Road, P. M. B 14, Ekpoma, Edo State, Federal Republic of Nigeria ${ }^{3}$ Synergy University,

80 Leningradskii Prospekt, Moscow, 125190, Russian Federation

凶agomado@inbox.ru

\begin{abstract}
The increasing investment of China in the Sub-Sahara Africa (SSA) has continued to add value to the continent of Africa. The Chinese investment has served as growth and developmental mechanism and finance sources for viable projects. The effect of China in Sub-Sahara Africa and Africa economies in generally on different dimensions, depending on the nature of the attractiveness of foreign direct investment (FDI) and factor of production of each country. The increased of China FDI inflows to SSA has generated much important gained to the continent of African economies. The authors analyze the FDI, determinants, merits and policy implications necessary to stimulate and accelerate more FDI from China and other countries of the world. In doing this, the SSA countries must have policy direction towards business friendly that would attract more investment and also protect foreign investors against expropriation.
\end{abstract}

Keywords: China, foreign direct investment, FDI, Sub-Sahara Africa, SSA

Article history: received June 12, 2021; revised June 17, 2021; accepted June 18, 2021.

For citation: Michael, M., Glory, E.O., Sylvester, O., \& Daniel, O.T. (2021). The Chinese foreign direct investment to Sub-Sahara Africa. RUDN Journal of Economics, 29(4), 796-805. http://dx.doi.org/10.22363/2313-2329-2021-29-4-796-805

\section{Прямые иностранные инвестиции Китая в страны Африки к югу от Сахары}

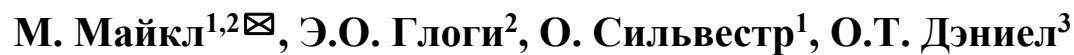 \\ ${ }^{1}$ Российский университет дружбы народов, \\ Российская Федерачия, 117198, Москва, ул. Миклухо-Маклая, д. 6 \\ ${ }^{2}$ Университет Амброуза Алли, \\ Федеративная Республика Нигерия, итат Эдо, Экпома, Р. М. B 14, KM 70 Benin Auchi Road \\ ${ }^{3}$ Университет «Синергия», \\ Российская Федерачия, 125190, Москва, Ленинградский пр-кт, д. 80
}

\agomado@inbox.ru

Аннотация. Увеличение инвестиций Китая в Африку к югу от Сахары по-прежнему повышает ценность Африканского континента. Китайские инвестиции служат механизмом роста и развития, а также источником финансирования жизнеспособных проектов.

(C) Michael M., Glory E.O., Sylvester O., Daniel O.T., 2021

(c) (1) This work is licensed under a Creative Commons Attribution 4.0 International License https://creativecommons.org/licenses/by/4.0/ 
Влияние Китая в странах Африки к югу от Сахары и в странах Африки в целом разнится в зависимости от характера привлекательности прямых иностранных инвестиций (ПИИ) и факторов производства каждой страны. Увеличение притока ПИИ из Китая в Африку к югу от Сахары внесло значительный вклад в экономику Африканского континента. Исследование посвящено анализу ПИИ, их преимуществ и политических последствий, детерминант, необходимых для стимулирования и ускорения роста ПИИ из Китая и других стран мира. При этом страны Африки к югу от Сахары должны проводить политику, направленную на создание благоприятных условий для бизнеса, которые привлекали бы больше инвестиций, а также защищали иностранных инвесторов от экспроприации.

Ключевые слова: Китай, прямые иностранные инвестиции, ПИИ, Страны Африки к югу от Сахары

История статьи: поступила в редакцию 12 июня 2021 г.; проверена 17 июня 2021 г.; принята к публикации 18 июня 2021 г.

Для цитирования: Michael M., Glory E.O., Sylvester O., Daniel O.T. The Chinese foreign direct investment to Sub-Sahara Africa // Вестник Российского университета дружбы народов. Серия: Экономика. 2021. Т. 29. № 4. С. 796-805. http://dx.doi.org/10.22363/23132329-2021-29-4-796-805

\section{Introduction}

In 2015, the New York United Nations summit, issues regarding Sustainable Development Goal (SGD) were adopted by leaders of various countries in pursuance to global growth and development. In sequel to the summit, huge success was recorded which was geared towards obtaining 2030 Millennium Development Goal (MDG) globally. One of such goals is to build sustainable infrastructure and accelerate industrialization (No. 9). As pointed out by United Nations Development Organizations ${ }^{1}$ emphasizes on the important of economic growth and development via cross border economic integration that will serve as a propeller for sustainable economic, social and environmental growth and development that are applicable to developed and less developing nations. This further reiterated that inequalities and wealth in developed and developing nations are as a result of the different economic growth models (industrialization/ investments) adopted by various countries. That it will take less developing countries over 100 years to obtained investment that will industrialized their various economic sectors and 50 years growing by $10 \%$ rate per annum and unfortunately, Africa has weak saving and investment base. Hence, for Sub-Sahara Africa (SSA) to achieve growth and development, investments is imperative and indispensable especially within the Sub-Sahara Africa nations having over $67 \%$ of less-developed economies in the world (Megbowon et al., 2019). Due to lack of capital for investment that can change the economic narrative of SSA, hence, it is necessary to have foreign direct investment (FDI) that is paramount to economic growth and development to Africa continent.

Thus, with economic integration, liberalization and globalization, FDI is playing germane roles in economic growth and development. Capital formation and technological advancement are theoretically considered as tools for socio-economic growth and development. Foreign direct investment to SSA has four important contribu-

${ }^{1}$ UNIDO. (2017). Statistical indicators of inclusive and sustainable industrialization baseline scenario. Retrieved April 20, 2021, from https://170302_UNIDO_Statistical-indicators-ofinclusive-and-sustainable-industrialization_ebook.pdf 
tions; to make up for domestic saving deficit; foreign exchange gap; revenue generation deficits and management, entrepreneurship, technology and skills. Liu, Hao and Gao (2017) noted that, to achieve economic sustainability and prosperity, FDI is imperative to employment generation, capital formation, economic growth and development, environmental sustainability industrialization among others. Most of the Sub-Sahara Africa countries lack the capacity to explore, refine and utilize their natural resources as a result of shortage of human and capital resources, inadequate technological advancement and socio-economic challenges.

However, many efforts have been made by SSA countries to stimulate and accelerate FDI inflows into the region by creating socio-economic policies, Export Processing Zones (EPZs) and investment zones via investment incentive such as tax holidays, duty free in some imported goods and equipment yet little has been achieved in economic growth and development. The level of poverty, unemployment, mortality rate, high level of uneducated people, corruption, social unrest, energy problem has increased significantly. It therefore requires that more prudence FDI are needed to address the socio-economic problem in Sub-Sahara Africa.

\section{Literature review}

Foreign direct investment is a key element in global economic integration and liberalization. Organization for Economic Cooperation and Development, ${ }^{2}$ view FDI as a means of creating direct, stable and long-lasting links between economies. Where the right socio-economic policies are in operation, it can serve as an important tool for the development of enterprise, and it may also help improve the competitiveness from the position the recipient and the investing economy. Foreign direct investment is an investment opportunity that involves relationship on long-term, lasting interest and control by a resident entity in one economy. ${ }^{3}$ FDI consists of international resources including technology, managerial and marketing expertise and capital. Foreign direct investment is viewed as a major stimulus to economic growth among countries. Although, the ability to deal with two major challenges, namely: shortages of financial resources, technology and skills, has made it the Centre of attraction for developing countries in particular. Only a few countries in the Sub-Saharan Africa have been successfully attracting significant FDI flow from China (Agwu, 2014).

China recently emerged on the global financial scene and one of the highest financiers, export destination, investment and development partner with FDI growing in the continent of Africa. This is attained as a result of Chinese government significant attachment to global growth and development considering the "Go Global" policy established in 1999. The policy recognized the growing awareness of Chinese government the opportunity to impact and goes beyond the territory of China and harnesses the economic potentials of other nations of the world (Luo et al., 2010). The policy serves as a determinant factor for Chinese investors to invest outside their domestic market and take advantage of the competitive business environment globally.

\footnotetext{
${ }^{2}$ OECD. (2008). OECD benchmark definition of foreign direct investment. 4th ed. France, OECD Publishing. Retrieved June 15, 2021, from https://www.oecd.org/daf/inv/investmentstatisticsandanalysis/40193734.pdf

${ }^{3}$ IMF. (2011). World Economic Outlook: A survey by the staff of the International Monetary Fund. Washington. Retrieved June 15, 2021, from https://www.imf.org/en/Publications/WEO
} 
As pointed out by Donou-Adonsou and Lim (2018), the increase in China's FDI to Sub-Sahara Africa are as a result of the visit of President Jiang Zemin in 1996 and President $\mathrm{Hu}$ Jintao to Africa in 2004 which serve as a driving force that help increase the markets and demand for resources to support China's growing economy with key commitment to grow and develop the continent of Africa respectively. Falki (2009) noted that the benefits of Chinese foreign direct investment on the host economy accelerate the increase in employment, productivity, encourage more exports and technology. The advantages of Chinese FDI in SSA economy is that it facilitates the utilization raw materials locally, new management techniques are introduced, change in marketing strategy and access to new technological advancement.

\section{Determinant of foreign direct investment inflow to Sub-Saharan Africa}

The literature on the forces driving Chinese FDI to Sub-Sahara Africa has identified policy and non-policy factors as a determinant of foreign direct investment (Asiedu, 2003). Policy factors are openness to other nations, product-market regulation, labour market arrangements, corporate tax rates, foreign investment restrictions, trade barriers and social amenities. Non-policy factors include market size of the receiving country, costs of transportation, socio-political and economic stability (Ayanwale, 2007). The pull factors include economic, socio-political and structural conditions, including uncertainty, while the push factors relate to cyclical and structural condition, irreversibility and herding (Gottschalk, 2001). The open market policy to attract FDI from China to SSA is yielding a lot of benefits to the continent of Africa, over $30 \%$ of foreign products coming to Africa are from China today and the Exim Bank of China is helping to promote greatly on the economic integration and liberalization with SSA countries.

Solomon and Eka (2013) also investigate the implication foreign direct investment aids and comparative advantage. Using two countries and two sector investment model to test for FDI using automobile and textile of each country, the finding reveals that the recipient country's more attractive to inward foreign investment than its comparative disadvantage sector. This shown that, the indicators of the FDI attractiveness depends on the socio-economic policies and market strength of the host countries. In SSA for instance, Chinese FDI inflows are so encouraging since the economic policies of the continent are gears towards having more foreign investors that will help change the economic situations. The importance of a wide range of institutional variables and government policy as determinants of the location of FDI and find that better institutions have overall positive and economically significant effect on FDI.

Bilateral and multilateral agreement between China and SSA are helping to attract more FDI from China to SSA and the establishment of regional economic policy such as the New Partnership for Africa Development (NEPAD). One of the major agreements is the Chinese-Africa Corporation Forum where partners meet every three years to review economic issues that will benefit and smoothening business relationship.

\section{China - Sub-Sahara Africa FDI}

Over a decade, the socio-economic relationship of China- Africa has significantly increased especially since the coming into existence of the forum on ChinaAfrica Cooperation (FOCAC), which has been serving as the engine room for 
strategy economic integration, cooperation and diplomatic relation. The economic integration between China and Sub-Sahara Africa involves investment, financed and trade relationship towards achieving a greater economic goal. All the Africa nations are benefiting over $45 \%$ foreign direct investment from China across all spheres of businesses from oil and gas sector, construction, manufacturing, extractive and financial services. The Chinese's banks (Exim bank of China) having been supporting infrastructural investment in Africa especially South Africa, Algeria, Angola, Ethiopia, Kenya Nigeria etc., currently over 2,300 private Chinese firms are operating in SSA. China foreign direct investment has increased tremendously because the Chinese government adopted various mechanisms to encourage investment oversea by making resources available for investment. The decaying energy and transport sectors attracted greater attention, agriculture, manufacturing sector are inclusive. In the transport sector the Chinese investors has done greatly in the construction of various railways line across the continent such as the Lagos Kano line, Nigeria, Benguela line, linking Angola and Zambia, Addis Ababa Djibouti line, Ethiopia, Mali - Guinea line, Kenya etc. China FDI in Sub-Sahara Africa has provided a new dimension and opportunities for African nations to benefits from the skills and technological advancement brought by the Chinese firms and this has provided jobs opportunities for the growing population especially in labour-intensive manufacturing industries. The Chinese FDI distribution in 21 selected countries in Sub-Sahara Africa from 2003-2019 is shown in Table.

FDI inflows from China to Sub-Sahara Africa for 17 years (2003-2019) under review shown that Algeria received 2770.90 million US dollar, Angola 2834.19 million US dollar, Cameroon 529.84, Republic of the Congo 1421.36, Democratic Republic of the Congo 3503.40, Cote d' Ivoire 546.24, Ethiopia 1957.07, Ghana 1558.13, Guinea 952.95, Kenya 1786.94, Madagascar 417.32, Mauritius 1327.21, Mozambique 1343.21, Niger 1152.80, Nigeria 2655.04, Seychelles 452.88, South Africa 9164.99, Tanzania 1320.93, Uganda 955.76, Zambia 3214.37 and Zimbabwe 1742.71 million US dollar. Within the period under review, the FDI from China to Sub Sahara Africa reveals that, South Africa recorded the highest value of 9164.99 million US dollar, follows by Zambia 3214.37 and 2834.19 million US dollar for Angola. Figure 1 shows that South Africa is the largest recipient (9164.99 million US dollar) of FDI inflow from China among all the selected countries. The least recipient is Chinese FDI is Seychelles with a value of 452.88 million US dollar within the period under review.

The general trends of Chinese FDI in SSA reveal a significant increase from time to time especially in some countries such as South Africa, Nigeria, Algeria, Angola etc., although decreases at time. In Nigeria for instance, Chinese investment cover different sector but largely in the construction, telecommunication and oil and gas industry. Meanwhile, China FDI are more concentrated in few SSA countries as a result of their natural resources - South Africa (Gold), Democratic Republic of the Congo (Diamond), Algeria (copper), Angola (Diamond), Nigeria(oil), Zambia (copper), Ethiopia (hydropower potentials) and Zimbabwe (Diamond) from 2003 to 2019 and favorable economic policy. These countries accounted for an average of $66 \%$ of the total FDI to SSA within the period under review. 
Chinese FDI distribution in 21 selected countries in Sub-Sahara Africa from 2003 to 2019, million US dollar

\begin{tabular}{|c|c|c|c|c|c|c|c|c|c|c|c|}
\hline & Algeria & Angola & $\begin{array}{c}\text { Came- } \\
\text { roon }\end{array}$ & $\begin{array}{c}\text { Republic } \\
\text { of the } \\
\text { Congo }\end{array}$ & $\begin{array}{l}\text { Demo- } \\
\text { cratic } \\
\text { Republic } \\
\text { of the } \\
\text { Congo }\end{array}$ & $\begin{array}{c}\text { Cote } \\
\text { d'Ivoire }\end{array}$ & Ethiopia & Ghana & Guinea & Kenya & $\begin{array}{l}\text { Mada- } \\
\text { gascar }\end{array}$ \\
\hline 2003 & 2.47 & 0.19 & 0.28 & 0.00 & 0.06 & 0.62 & 0.98 & 2.89 & 1.20 & 0.74 & 0.68 \\
\hline 2004 & 11.21 & 0.18 & 0.37 & 0.51 & 11.91 & 6.75 & 0.43 & 0.34 & 14.44 & 2.68 & 13.64 \\
\hline 2005 & 84.87 & 0.47 & 0.19 & 8.11 & 5.07 & 8.74 & 4.93 & 2.57 & 16.34 & 2.05 & 0.14 \\
\hline 2006 & 98.93 & 22.39 & 0.73 & 13.24 & 36.73 & 2.91 & 23.95 & 0.50 & 0.75 & 0.18 & 1.17 \\
\hline 2007 & 145.92 & 41.19 & 2.05 & 2.50 & 57.27 & 1.74 & 13.28 & 1.85 & 13.20 & 8.90 & 13.24 \\
\hline 2008 & 42.25 & 9.57 & 1.69 & 9.79 & 23.99 & 7.02 & 9.71 & 10.99 & 8.32 & 23.23 & 61.16 \\
\hline 2009 & 228.76 & 8.31 & 0.82 & 28.07 & 227.16 & 1.51 & 74.29 & 49.35 & 26.98 & 28.12 & 42.56 \\
\hline 2010 & 186.00 & 101.11 & 14.88 & 34.38 & 236.19 & 5.02 & 58.53 & 55.98 & 9.74 & 101.22 & 33.58 \\
\hline 2011 & 114.34 & 72.72 & 1.87 & 6.81 & 75.18 & 0.87 & 72.30 & 40.07 & 24.55 & 68.17 & 23.10 \\
\hline 2012 & 245.88 & 392.08 & 17.65 & 98.80 & 344.17 & 3.61 & 121.56 & 208.49 & 64.44 & 78.73 & 8.43 \\
\hline 2013 & 191.30 & 224.05 & 57.20 & 109.94 & 121.27 & 4.79 & 102.46 & 122.51 & 100.13 & 230.54 & 15.51 \\
\hline 2014 & 665.71 & 448.57 & 29.74 & 238.60 & 157.56 & 24.26 & 119.59 & 72.90 & 67.70 & 278.39 & 36.76 \\
\hline 2015 & 210.57 & 57.74 & 24.67 & 150.08 & 213.71 & 60.24 & 175.29 & 283.22 & 25.72 & 281.81 & 33.84 \\
\hline 2016 & 99.89 & 164.49 & 114.23 & 49.13 & -78.92 & 56.53 & 282.14 & 490.61 & 36.67 & 29.67 & 6.55 \\
\hline 2017 & 140.53 & 637.55 & 87.99 & 284.17 & 340.24 & 112.69 & 181.08 & 44.20 & 286.56 & 410.10 & 71.20 \\
\hline 2018 & 178.65 & 270.34 & 141.79 & 292.64 & 643.01 & 163.68 & 341.3 & 142.25 & 203.17 & 232.04 & 55.6 \\
\hline 2019 & 123.62 & 383.24 & 33.69 & 94.59 & 930.96 & 85.26 & 375.3 & 29.41 & 53.04 & 10.37 & 0.16 \\
\hline
\end{tabular}

\begin{tabular}{lcccccccccc}
\hline & Mauritius & $\begin{array}{c}\text { Mozam- } \\
\text { bique }\end{array}$ & Niger & Nigeria & $\begin{array}{c}\text { Seychel- } \\
\text { les }\end{array}$ & $\begin{array}{c}\text { South } \\
\text { Africa }\end{array}$ & Tanzania & Uganda & Zambia & Zimbabwe \\
\hline $\mathbf{2 0 0 3}$ & 10.27 & 0.00 & 0.00 & 24.40 & 0.00 & 8.86 & 0.00 & 1.00 & 5.53 & 0.03 \\
$\mathbf{2 0 0 4}$ & 0.44 & 0.66 & 1.53 & 45.52 & 0.00 & 17.81 & 1.62 & 0.15 & 2.23 & 0.71 \\
$\mathbf{2 0 0 5}$ & 2.04 & 2.88 & 5.76 & 53.30 & 0.05 & 47.47 & 0.96 & 0.17 & 10.09 & 1.47 \\
$\mathbf{2 0 0 6}$ & 16.59 & 0.00 & 7.94 & 67.79 & 0.06 & 40.74 & 12.54 & 0.23 & 87.44 & 3.42 \\
$\mathbf{2 0 0 7}$ & 15.58 & 10.03 & 100.83 & 390.35 & 0.09 & 454.41 & 3.82 & 4.01 & 119.34 & 12.57 \\
$\mathbf{2 0 0 8}$ & 34.44 & 5.85 & 0.01 & 162.56 & 0.05 & 4807.86 & 18.22 & 6.70 & 213.97 & 0.72 \\
$\mathbf{2 0 0 9}$ & 14.12 & 15.85 & 39.87 & 171.86 & 0.36 & 41.59 & 21.58 & 1.29 & 111.80 & 11.24 \\
$\mathbf{2 0 1 0}$ & 22.01 & 0.28 & 196.25 & 184.89 & 12.28 & 411.17 & 25.72 & 26.50 & 75.05 & 33.80 \\
$\mathbf{2 0 1 1}$ & 419.46 & 20.26 & 51.63 & 197.42 & 4.34 & 14.17 & 53.12 & 9.91 & 291.78 & 440.03 \\
$\mathbf{2 0 1 2}$ & 57.83 & 230.52 & 195.94 & 333.05 & 53.40 & 814.91 & 119.70 & 9.79 & 291.55 & 287.47 \\
$\mathbf{2 0 1 3}$ & 61.07 & 131.89 & 116.54 & 209.13 & 17.69 & 89.19 & 150.64 & 60.60 & 292.86 & 517.53 \\
$\mathbf{2 0 1 4}$ & 49.43 & 102.51 & 44.61 & 199.77 & 7.56 & 42.09 & 166.61 & 60.50 & 424.85 & 101.18 \\
$\mathbf{2 0 1 5}$ & 154.77 & 68.43 & 23.69 & 50.58 & 49.58 & 233.17 & 226.32 & 205.34 & 96.55 & 46.75 \\
$\mathbf{2 0 1 6}$ & 72.33 & 44.25 & 23.56 & 108.50 & 50.41 & 843.22 & 94.57 & 121.51 & 218.41 & 42.95 \\
$\mathbf{2 0 1 7}$ & 33.27 & 117.47 & 50.84 & 137.95 & 27.05 & 317.36 & 132.46 & 79.04 & 305.80 & 107.88 \\
$\mathbf{2 0 1 8}$ & 178.2 & 545.63 & 115.44 & 194.7 & 227.98 & 642.06 & 177.47 & 225.8 & 523.73 & 53.83 \\
$\mathbf{2 0 1 9}$ & 185.9 & 46.7 & 178.36 & 123.3 & 1.98 & 338.91 & 115.58 & 143.22 & 143.39 & 81.13 \\
\hline
\end{tabular}

Source: The Statistical Bulletin of China's Outward Foreign Direct Investment published by China's MOFCOM. Retrieved June 15, 2021, from http://fec.mofcom.gov.cn/article/tjsj/ 


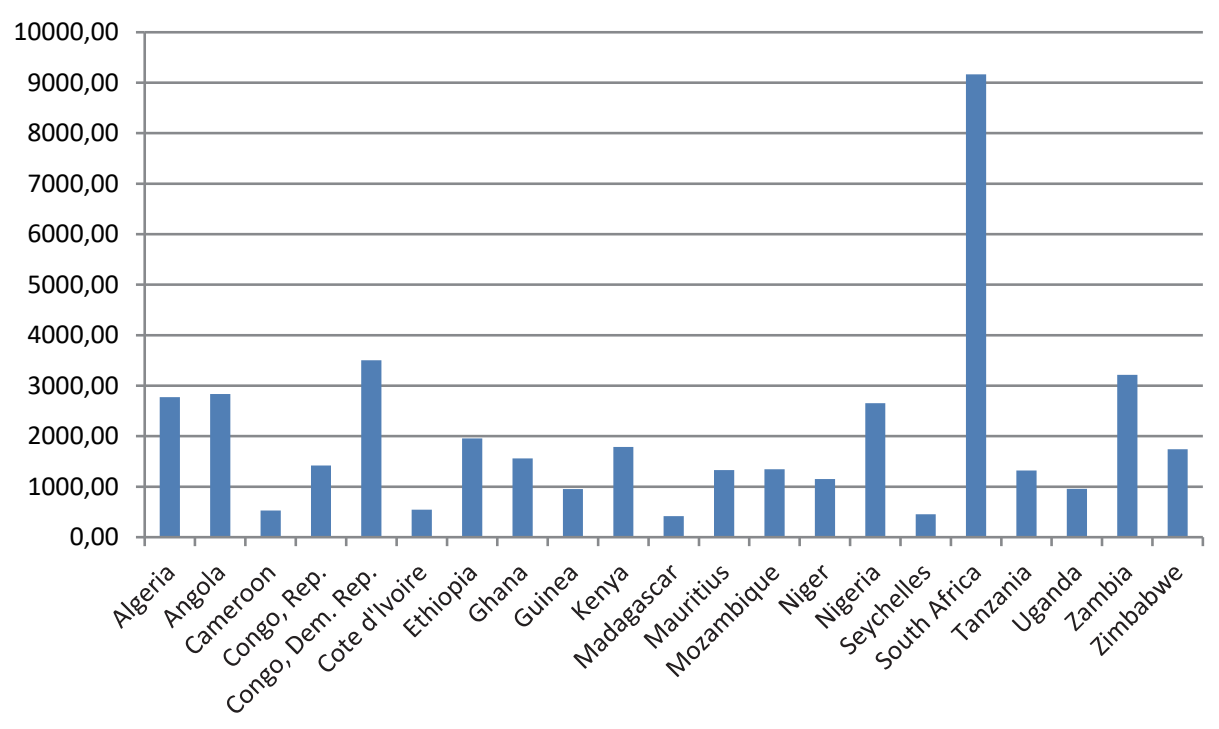

Figure 1. China FDI flows distribution to Sub-Sahara Africa from 2003 to 2019, million US dollar

Source: The Statistical Bulletin of China's Outward Foreign Direct Investment published by China's MOFCOM. Retrieved June 15, 2021, from http://fec.mofcom.gov.cn/article/tjsj/

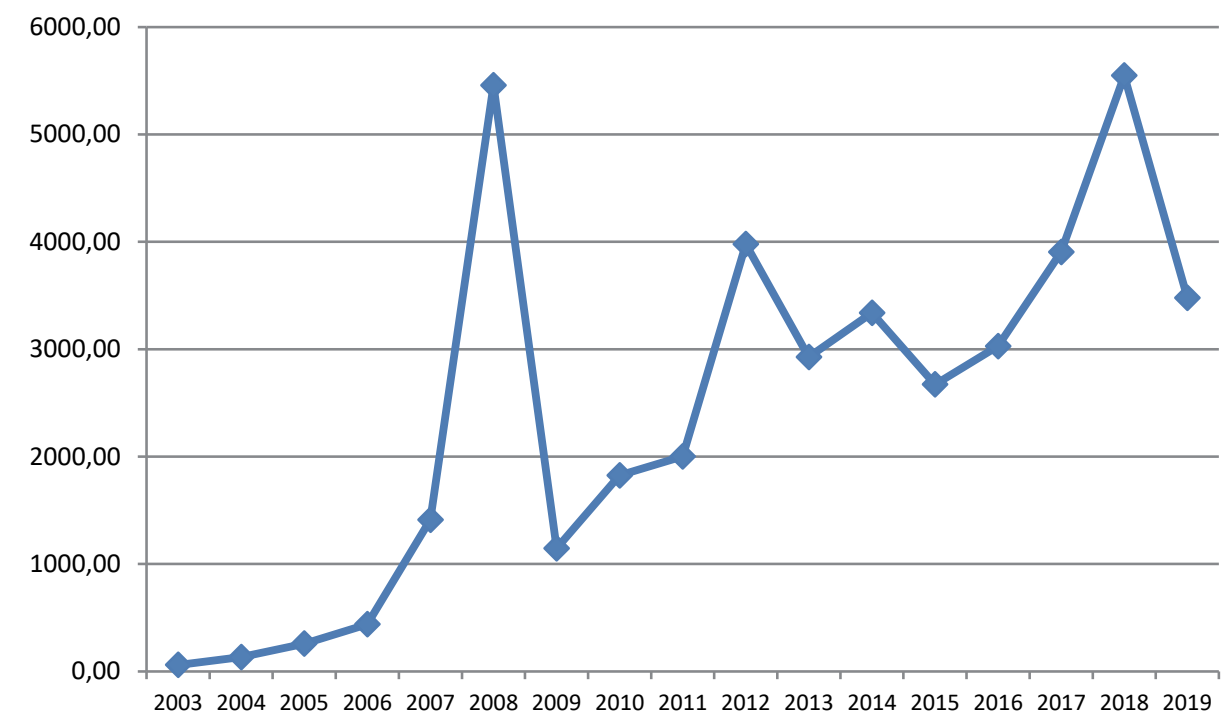

Figure 2. Total China FDI flow to Sub-Sahara Africa from 2003 to 2019 , million US dollar

Source: The Statistical Bulletin of China's Outward Foreign Direct Investment published by China's MOFCOM. Retrieved June 15, 2021, from http://fec.mofcom.gov.cn/article/tjsj/

The total value of China FDI to 21 selected Sub-Sahara Africa countries from 2003 to 2019 depicts on Figure 2 reveals that 2003 value of FDI received from China stood at 60.20 million US dollar, and rose to 5458.10 million US dollar in 2008 but decrease to 1145.49 million US dollar in 2009. In 2010 to 2012, the value of inflows from China maintained a progressive trend from 1824.58 million US dollar to 3978 million US dollar but decreased to 1038.11 million US dol- 
lar in 2013. However, 2014 value was 3338.89 million US dollar, decrease in 2015 to 2672.07 and rose to 3028.54 million US dollar in 2016. In 2017 inflow was 3905.43 million US dollar, increase in 2018 to 5549.27 and decrease to 3478.07 in 2019. The FDI inflow to the selected Sub-Sahara Africa countries from China was lowest in 2003 valued at 60.20 and highest value of 5549.27 million US dollar in 2018 respectively. The tremendous increase of FDI in 2018 is as result of the more investment inflows into agriculture, mining, quarrying and petroleum ${ }^{4}$ and the manufacturing sector (food beverages, tobacco, pharmaceuticals, medicals, chemicals and botanical products).

Again, China FDI inflows created over 137, 028 jobs from 2014 to 2018 in 259 projects (FDI Intelligence and EY Africa Attractiveness Report, 2019). For instance, Ghana Investment Promotion Centre (2013) reported that, the Chinese FDI generated 18,963 jobs in Ghana of which 15,903 were Ghanaians and 3060 were for non-Ghanaians. The manufacturing sector had the highest value of 7,355, trading 3987, building and construction 3167 and lastly liaison 212. Again, Ethiopia and Rwandan are not left out in the jobs generation, between 2003-2014, 3,811 jobs were created, the construction sector taking the lead 1415, extraction second 1064 , manufacturing 510, ICT and internet infrastructure 322, logistics 133, education and training 75, electricity 66, retail 38, business services 17 , sales, marketing 15 and other businesses $156 .{ }^{5}$ In 2019, FDI greenfield investment monitoring market reported that 170 manufacturing FDI project were executed in Sub-Sahara Africa, which exceeded the previous annual average of 109 projects with estimated increase in jobs creation by $92 \%$ to 33,855 . Kenya, Uganda, Malawi and Ghana recorded a significant improvement in Greenfield manufacturing and agricultural business was the most active during the period of 2019, meanwhile 2017, the construction and mining industry accounted for over $52 \%$ of China FDI to SSA. ${ }^{6}$

The Figure 3 reveals that, 2017 top five sectors for China's FDI to SSA. FDI inflows to construction was $29.80 \%$, mining $22.5 \%$, manufacturing $14 \%$, finance $13.2 \%$, leasing and business services $5.3 \%$ and others $15.2 \%$. The investment in manufacturing, mining and construction sector accounted for $66.3 \%$ of total FDI in 2017. UNCTAD reveals that, the Greenfield FDI in manufacturing sector (clothing, leather and textiles) are relatively 20 times stable compare to previous years. ${ }^{7}$ The investments in the manufacturing industry are germane to SSA economic diversification which represents a larger portion of total GDP. However, the Chinese FDI are helping in accelerating the rate of investment especially in the area of skills, knowledge and technology transfers in less develop nations. The growth and development of the many sectors leads to the provision of employment for the growing population in SSA.

${ }^{4}$ UNCTAD. (2019). World investment report: Special economic zones. New York, United Nations Publishing. Retrieved June 15, 2021, from https://unctad.org/system/files/officialdocument/wir2019_en.pdf

${ }^{5}$ MOFCOM. (2012). Annual cooperative audit online of national foreign investment enterprises. Beijing. Retrieved April 12, 2021, from http://www.fdi.gov.cn/1800000121_10000029_8.html

${ }^{6}$ UNCTAD. (2018). World investment report: Investment and new industrial policies. New York, United Nations Publishing. Retrieved June 15, 2021, from https://unctad.org/system/files/officialdocument/wir2018_en.pdf

${ }^{7}$ Ibid. 


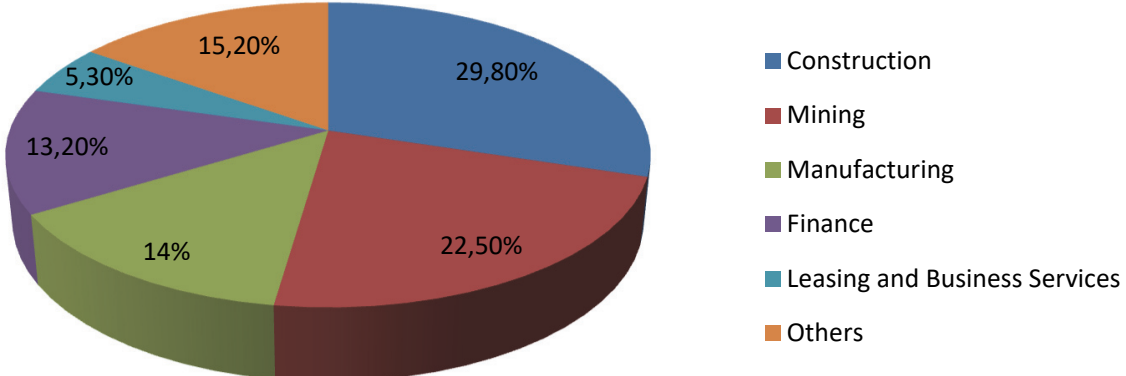

Figure 3. Top five most finance sectors by China FDI in 2017 for Sub-Sahara Africa

Source: Statistical Bulletin of China's Outward Foreign Direct Investment 2017. Retrieved June 15, 2021, from https://www. purpleculture.net/statistical-bulletin-of-chinas-outward-foreign-direct-investment-bs-1117/

\section{Conclusion}

Foreign direct investments enhance economic growth and development in the recipient country. Sub-Sahara Africa countries are beneficiaries of foreign direct investment from China. In spite of the laudable economic benefits of Chinese FDI in telecommunication, manufacturing, banking, transportation and construction industry to the recipient countries in Sub-Sahara Africa, the living standard of the people and social infrastructural facilities, employment conditions and many others remain on the increase. Chinese investors should be encouraged by the SSA to invest in various industries in nation economies in the continent of Africa. This can be done by improving the financial markets to attract Chinese foreigners to invest their money in various securities such as corporate bonds and equities (stocks). SSA must ensure that China investors are doing businesses in accordance with the laws and regulations governing business operations; A Memorandum of Understanding (MOU) between SSA and Chinese investors should be entered into to encourage Public-Private Partnership (PPP) and increase the investment opportunities in the country. Foreign investors must be protected against nationalization and expropriation.

\section{References}

Agwu, M.E. (2014). Foreign direct investments: A review from the Nigerian Perspective. Research Journal of Business and Management, (1(3)), 318-337.

Asiedu, E. (2003). Capital controls and foreign direct investment. World Development, 32(3), 479-490.

Ayanwale, A.B. (2007). FDI and economic growth: Evidence from Nigeria. AERC Research Paper 165. African Economic Research Consortium, Nairobi. Retrieved April 12, 2021, from www.aercafrica. org/ documents/rp_165.pdf

Boldeanu, F.T., \& Constantinescu, L. (2015). The main determinants affecting economic growth. Bulletin of the Transilvania University of Brassov. Series V: Economic Sciences, 8(2), 329-338. Retrieved June 15, 2021, from https://ashraffeps.yolasite.com/resources/EuroMed/Fall2018/The\%20main\%20determi nants\%20affecting\%20economic\%20growth.pdf

Borensztein, E., De Gregorio, J., \& Lee, J.W. (1998). How does foreign direct investment affect economic growth? Journal of International Economics, 45(1), 115-135. 
Donou-Adonsou, F., \& Lim, S. (2018). On the importance of Chinese investment in Africa. Review of Development Finance, 8(1), 63-73. Retrieved June 15, 2021, from https://www.sciencedirect.com/science/article/pii/S1879933718300551?via\%3Dihub

Falki, N. (2009). Impact of foreign direct investment on economic growth in Pakistan. International Review of Business Research Papers, (5(5)), 110-120.

Gorg, H., \& Greenway, D. (2004). Much ado about nothing? Do domestic firms really benefits from foreign investment? The World Bank Research Observer, 19, 171-197.

Gottschalk, R. (2001). Lenders and investors' international portfolio allocation decisions: What do we know? Sussex, Institute of Development Studies.

Liu, Y., Hao, Y., \& Gao, Y. (2017). The environmental consequences of domestic and foreign investment: Evidence from China. Energy Policy, 108, 271-280. https://doi.org/10.1016/j.enpol.2017.05.055

Luo, Y., Xue, Q., \& Han, B. (2010). How emerging market governments promote outward FDI: Experience from China. Journal of World Business, 45(1), 68-79. https://doi.org/10.1016/j.jwb.2009.04.003

Megbowon, C., Mlambo, C., \& Adekunle, B. (2019). Impact of China's outward FDI on SubSaharan Africa's industrialization: Evidence from 26 countries. Cogent Economics \& Finance, 7, 1-14. https://doi.org/10.1080/23322039.2019.1681054

Olofsdotter, K. (1998). Foreign direct investment, country capabilities and economic growth. Weltwitschaflliches Arckive, 134(3), 534-547.

Phillips, P.C.B., \& Perron, P. (1988). Testing for a unit root in time series regression. Biometrika, 75, 335-346.

Pigato, M., \& Tang, W. (2015). China and Africa: Expanding economic ties in an evolving global context. Working Paper Series, Addis Ababa, Ethiopia.

Sahoo, K., \& Sethi, N. (2017). Impact of foreign capital on economic development in India: An econometric investigation. Global Business Review, 18(3), 1-15. https://doi.org/10.1177/0972150917692198 http://gbr.sagepub.com

Shahbaz, M., \& Rahman, M.M. (2010). Foreign capital inflows-growth nexus and role of domestic financial sector: An ARDL co-integration approach for Pakistan. J. Econ. Res., 15, 207-231.

Solomon, H.C., \& Eka, O.O. (2013). Impact of foreign direct investment on telecommunication sector on Nigerian economy. International Journal of Modern Social Sciences, 2(3), 195-215.

\section{Сведения об авторах / Bio notes}

Мадоджему Майкл, аспирант, кафедра международных экономических отношений, экономический факультет, Российский университет дружбы народов; преподаватель, Университет Амброуза Алли. E-mail: agomado@inbox.ru

Эхичиоя Отоекпашян Глори, доктор философии, старший преподаватель, Университет Амброуза Алли. E-mail: ehichioyaotorkpashanglory@gmail.com

Оби Сильвестр, аспирант, кафедра всеобщей истории, Российский университет дружбы народов. E-mail: fabiofreed@yahoo.com

Оланреваджу Темидайо Даниэль, магистрант, кафедра гражданского права, Университет «Синергия». E-mail: dtemidayo@mail.ru
Madojemu Michael, postgraduate student, Department of International Economic Relations (World Economy), Peoples' Friendship University of Russia (RUDN University); part time lecturer, Ambrose Alli University. E-mail: agomado@inbox.ru

Ehichioya Otoekpashian Glory, $\mathrm{PhD}$, senior lecturer, Ambrose Alli University. E-mail: ehichioyaotorkpashanglory@gmail.com

Obi Sylvester, postgraduate student, Department of General History, Peoples' Friendship University of Russia (RUDN University). E-mail: fabiofreed@yahoo.com

Olanrewaju Temidayo Daniel, master student, Department of Civil Law, Synergy University. E-mail: dtemidayo@mail.ru 